\title{
Online Alışverişlerde Kargo Hizmetlerinin Tüketici Algılarına Etkisi
}

\author{
DOI: $10.26466 /$ opus.681809
}

*

\section{Mertcan Taşçığlu *}

* Dr. Öğr. Üyesi, İstanbul Medeniyet Üniversitesi, Siyasal Bilgiler Fakültesi, İstanbul/Türkiye E-Posta: mertcan.tascioglu@medeniyet.edu.tr $\quad$ ORCID: 0000-0003-4024-2453

\section{Öz}

Günümüzde online alışverişlerin önemi giderek artmakta, tüketicilerin alışveriş alışkanlıkları değgişirken alışverişlerini online mağazalardan yapanların sayısında da önemli bir artış gözlenmektedir. Bununla parallel olarak online mağaza açan şirketlerin sayısı da giderek çoğalmakta ve şirketlerin sundukları hizmetler de çeşitlenmektedir. Bu bağlamda sunulan kargo hizmetleri de tüketiciler için önemli hale gelmiş, satın alma kararında önemli bir etken haline gelmiştir. Özellikle online alışverişlerde sunulan kargo hizmetlerinin çeşitliliği, siparişin gönderileceği kargo şirketini seçebilme imkanı, kargonun tüketiciye ulaşma hızı gibi konular tüketicilerin alışveriş yaptıkları online mağazaları seçerken dikkat ettikleri unsurların başında gelmektedir. Bu çalışmada senaryo bazh deney yöntemi kullanılarak kargo ücretinin tahsil zamanı, kargonun ulaşma süresi ve kargo şirketini seçme imkanı manipüle edilerek online alışveriş niyeti, online tüketici tatmini ve algllanan hizmet kalitesi üzerindeki etkileri incelenmiştir. Sonuçlar kargo ücretinin satın alma sırasında ödenmesinin, ürün tesliminin üç iş günü içinde yapılmasının ve kargo şirketini seçebilme imkanı olmasının online alışveriş niyetini, online tüketici tatminini ve algilanan hizmet kalitesini artırdığını göstermektedir.

Anahtar Kelimeler: $\quad$ Kargo Hizmetleri, Online Alışveriş, Tüketici Tatmini, Alışveriş Niyeti, Algilanan Hizmet Kalitesi 


\title{
The Effect of Courier Services on Consumer Perceptions in Online Shopping
}

\begin{abstract}
Today, the importance of online shopping is gradually increasing, while the shopping habits of consumers are changing, a significant increase is observed in the number of people who shop online. In parallel, the number of companies that open online stores is increasing, and the services offered by companies are diversified. In this context, the courier services offered have also become important for consumers and have become an important factor in the purchase decision. Issues such as the variety of courier services offered in online shopping, the possibility of choosing the courier company to which the order will be sent, and the speed of cargo reaching to the consumer are among the primary factors that consumers pay attention to when choosing the online stores where they shop. In this study, using the scenario-based experiment method, the time of collecting the shipping fee, the shipping time of the parcel and the choice of the shipping company were manipulated and the effects on the intention of online shopping, online consumer satisfaction and perceived service quality were examined. The results show that the payment of the parcel at the time of purchase, the delivery of the product within three working days and the possibility of choosing the shipping company increases the online shopping intention, online consumer satisfaction and perceived service quality.
\end{abstract}

Keywords: Courier Services, Online Shopping, Consumer Satisfaction, Shopping Intention, Perceived Service Quality 


\section{Giriş}

Günümüzde tüketiciler günlük hayatları içerisinde alışveriş için yeterli zaman ayırma imkanına sahip değillerdir. Gerek iş yaşamının yoğunluğu, gerekse de alışveriş için farklı mağazalara ulaşmanın zorluğu tüketicilerin online alışveriş sitelerine yönlenmesine yol açmıştır. Son yıllarda hem dünyada hem de ülkemizde elektronik ticaret alanında önemli gelişmeler yaşanmış, büyük sermaye sahipleri yatırımları bu alana yoğunlaştırmışlardır. Günümüzde dünyanın en zengin insanları arasında yer alan Jeff Bezos, dünyanın online ticaret konusunda en büyük firmalarından biri olan Amazon.com'un kurucusu ve sahibidir. Amazon.com'un kuruluşundan itibaren 25 yıl gibi (1994 - 2019) bir işletme için çok kısa sayılabilecek bir sürede yıllık 279 milyar dolar gelir elde eden bir şirket haline gelmesi (Forbes, 2019) diğer işletmeleri de elektronik ticaret alanında yatırım yapmaya yönlendirmiştir. Önümüzdeki yıllarda online alışverişin payı artarak büyümeye devam edecektir.

Bu yeni durum tüketicilerin beklentilerini ve memnuniyet kriterlerinde de bazı değişimlere yol açmıştr. Online alışveriş ile birlikte, ürünlerin tüketicilerin eline en hızlı ve en kolay şekilde ulaşması da önemli bir hal almıştır. Bu amaçla faaliyet gösteren kargo firmalarının sayılarında artış olduğu gibi, bazı online satış siteleri kendilerine özel kargo dağıtım sistemleri kurmuşlardır. Tüketiciler internetten ürün almakla birlikte, kargo firmaları aracılığı ile ürünlerin tüketicilere teslimi hizmet alanında değerlendirilmektedir. Hizmetlerin ürünlere göre en önemli farkı soyut olmalarıdır. Soyut olan hizmetlerin değerlendirilmesi, ve hizmet işletmelerinin kıyaslanması ürünlere göre daha zor olmaktadır. Hizmet sunumunda standart sağlamak oldukça güç olmaktadır. Bu durumdan kargo firmaları da etkilenmekte ve tüketicilerin bu konuda birçok memnuniyetsizlik yaşamalarına yol açabilmektedirler. Günümüzde tüketiciler, şikayetlerini gerek ilgili işletmeye ileterek, gerekse de başka tüketicilerle paylaşımda bulunarak hem yaşanan olumsuz durumların ortadan kaldırılmasını talep etmekte, hem de bir anlamda işletmeleri cezalandırmaktadırlar. Sadece tüketici şikayetlerini paylaşmak amacıyla faaliyet gösteren internet siteleri bulunmaktadır. Bu siteler incelendiğinde ise kargo firmaları ile ilgili oldukça fazla şikayet olduğu görülmektedir.

Hizmetlerin, faaliyet gösterilen tüm bölgelerde aynı şekilde sunulması zor olabilmektedir. Bu nedenle bazı bölgelerde bazı kargo firmalarına ait 
şikayetler yoğunlaşırken, aynı firmanın farklı bir bölgedeki hizmetleri tüketicileri memnun edebilmektedir. Hizmetlerde mevsimsel olarak da sikıntılar yaşanabilmektedir. Son yıllarda ülkemizde de yaygınlaşan "Çılgın Cuma", "Efsane Cuma" gibi etkinlikler tüketicilerin yıl boyunca bekledikleri indirimlere ulaşarak normal zamanlara kıyasla çok daha fazla alışveriş yapmalarına sebep olmaktadır. Ancak bunun sonucunda kargo firmalarının yükü çok yüksek oranda artmakta ve ürünlerin teslimi için tüketicilerin olukça uzun süre beklemeyi göze almaları gerekmektedir. Bu bekleme süresi örneğin 2019 yılında gerçekleştirilen kampanya döneminde haftaları bulmuştur. Uzun bekleme süreleri tüketicilerin yaptıkları alışverişten memnuniyetleri üzerinde olumsuz etki yapabilmektedir.

Tüketicilerin online olarak yaptıkları alışverişlerde karşılaştıkları bir diğer durum ise kargo ücretinin alışverişin hangi aşamasında ödeneceğidir. Kargo ücreti ürün satın alırken ödenebileceği gibi, ürünün teslimi sırasında da ödenebilmektedir. Her iki durumun da tüketiciler için avantajları bulunmaktadır. Örneğin ürün tesliminde kargo ücretinin ödenmesi, gelen üründe bir sorun bulunması durumunda tercih edilebilecek bir seçenekken, satın alma esnasında ödenmesi, tüketicilerin kargo ücretinin ürünün fiyatının bir parçası olarak görerek, tek fiyat şeklinde değerlendirmesine sebep olmaktadır.

Bu çalışmada satın alınan ürünlerin tüketicilere ulaşma süresinin, kargo ücretinin alışverişin hangi aşamasında ödeneceğinin ve kargo firması ile ilgili olarak tüketicilerin seçim imkanına sahip olup olmamalarının, tüketicilerin online alışveriş niyetleri, tüketici tatminleri ve algıladıkları hizmet kalitesi üzerindeki etkisi araştırılmıştır.

\section{Literatür İncelemesi}

Online hizmet kalitesi web siteleri üzerinden tüketiciler tarafından algılanan memnuniyet seviyesi ile ilgili bir kavramdır (Ahn vd., 2007; Santouridis vd., 2009). İnternet siteleri aracılığı ile yapılan alışverişlerde kişilerle iletişim kurmak gerekmemektedir, bu nedenle de tüketicilerin yapacakları değerlendirmelerde de hizmet kalitesi en önemli unsur haline gelmektedir (Zeithaml vd., 2002). Online hizmet kalitesinde, internet sitesinin kullanım kolaylığı gibi online özellikler önemliyken, aynı zamanda ürün teslimatı ve müşteri şikayetlerinin etkin bir biçimde çözüme kavuşturulması gibi site dışı özellikler de önemlidir (Khalifa ve Liu 2007). 
Online alışveriş, tüm dünya genelinde giderek artan bir kabul görmektedir (Abramovic, 2019). Çevrimiçi alışveriş siteleri fiziksel mağazaların yerini almaktadır (Nanji, 2013). Online alışverişin bu kadar hızlı artışına yol açan nedenler arasında ödeme kolaylığı ve zamandan tasarruf yer almaktadır (Alreck vd., 2009). Online mağazalar, sanal bir dünyada tüketicilere fiziksel bir alışveriş deneyiminin olanaklarını yaşatmayı amaçlamaktadır (Verhagen vd., 2014). Böylelikle tüketicilerin algıladıkları risklerin azalması ve online alışveriş niyetinin yükselmesi mümkün olmaktadır (Nepomuceno vd., 2014). Niyet insanların davranışlarında önemli belirleyicilerden biridir. İnsanların niyetleri ile davranışları arasında belirli ölçüde bir tutarlılık olması gerekmektedir (Bhattacherjee, 2001). Bu nedenle tüketicileri belirli davranışlara yöneltmenin şartlarından biri, onların ilgili konularda bir niyete sahip olmalarını sağlamaktır. Tüketicilerin online alışveriş yapma niyeti, bir İnternet mağazasından alışveriş yapma istekliliğini ifade eder. Genellikle, bu faktör tüketicilerin satın alımları ve başka zamanda yine alışveriş yapmak amacıyla geri dönme istekliliği ile ölçülmektedir (Li ve Zhang, 2002). Online alışveriş niyeti müşteri sadakatine de katkıda bulunmaktadır. Jarvenpaa vd (2000), tüketicilerin online alışveriş niyetini, tüketicilerin gelecek üç ay ve bir yıl içinde aynı mağazadan satın alma ihtimalini belirleyerek ölçmeye çalışmışlardır.

Algılanan hizmet kalitesi Parasuraman vd (1988) tarafindan "hizmetin üstünlüğüne ilişkin evrensel bir yargı ya da tutum" olarak tanımlanırken birçok araştırmacı da bu tanımla aynı görüştedir (Boulding vd, 1993; Bolton ve Drew, 1991; Cronin ve Taylor, 1992). Tüketici tatmininin tanımı ise hizmet kalitesi kadar net değildir. Tanımında bir fikir birliği olmamakla beraber, birçok tanımın içeriğinde "değerlendirme ve duygusal bir tepki" kavramları yer almaktadır (Oliver ve DeSarbo, 1989, s.1).

Hem tatmin hem de hizmet kalitesi literatürü, tüketicilerin ürün veya hizmetin performansı ile bazı standartlar arasında bir karşılaştırma yaptığı fikrini vurgulamaktadır (Spreng ve Mackoy, 1996). Hizmet kalitesi literatürü, algılanan hizmet kalitesi ile tatmin kavramları arasındaki farkı belirtmiş, bu kavramların kullandıkları standartların ve karşılaştırma yöntemlerinin farklarına işaret etmektedirler (Bitner, 1990; Parasuraman vd. 1988, Zeithaml vd. 1993). Hizmet kalitesini ve tatmini entegre etmeye çalışan kavramsal bir modelde, Oliver (1993) kalite algısı ile tatmin kavramlarının öncüllerinin birbirlerinden farklı olduğunu, dolayısıyla kavramların da birbirlerinden farklı olduklarını belirtmiştir. 
Tüketici memnuniyeti, tüketicilerin online alışveriş deneyimine ilişkin algıları ile beklentilerinin ne ölçüde örtüştüğü olarak tanımlanabilir. Tüketicilerin çoğu, online alışverişe başlamadan önce, ilgili web sitesinin ürün, satıcl, hizmet ve kalitesine dair bir beklenti içerisine girmektedirler. Bu beklentiler, belirli bir internet mağazasından alışveriş yapma tutumlarını ve niyetlerini ve sonuç olarak karar alma süreçlerini ve satın alma davranışlarını etkilemektedir. Beklentilerinin karşılanması durumunda, müşteriler online alışveriş niyetlerini olumlu yönde etkileyecek yüksek bir memnuniyet derecesine ulaşacaklardır (Ho ve Wu 1999; Jahng vd., 2001; Kim vd., 2001). Bu çalışmada online alışverişlerde çeşitli kargo hizmetlerinin alışveriş niyeti, tüketici tatmini ve algılanan hizmet kalitesi üzerindeki etkilerini tek tek ve ikili etkileşim olarak ölçmek için aşağıdaki hipotezler geliştirilmiştir.

- H1: Online alışverişlerde kargo ücretinin satın alma sırasında ödenmesinin, ürün tüketiciye ulaştı̆̆ında ödenmesine kıyasla a) online alışveriş niyeti, b) online tüketici tatmini ve c) algılanan hizmet kalitesi üzerinde daha fazla pozitif etkisi vardır.

- H2: Online alışverişlerde ürün tesliminin üç iş günü içinde olmasının, dört-altı iş günü içinde olmasına kıyasla a) online alışveriş niyeti, b) online tüketici tatmini ve c) algilanan hizmet kalitesi üzerinde daha fazla pozitif etkisi vardır.

- H3: Online alışverişlerde kargo şirketini seçebilme imkânı olmasının, olmamasına kıyasla a) online alışveriş niyeti, b) online tüketici tatmini ve c) algılanan hizmet kalitesi üzerinde daha fazla pozitif etkisi vardır.

- H4: Online alışverişlerde kargo ücretinin satın alma sırasında ödenebiliyor olması, ürün tesliminin üç iş günü içinde olmasının a) online alışveriş niyeti, b) online tüketici tatmini ve c) algılanan hizmet kalitesi üzerindeki pozitif etkisini artırmaktadır.

- H5: Online alışverişlerde kargo ücretinin satın alma sırasında ödenebiliyor olması, kargo şirketini seçebilme imkânı olmasının a) online alışveriş niyeti, b) online tüketici tatmini ve c) algılanan hizmet kalitesi üzerindeki pozitif etkisini artırmaktadır.

- H6: Online alışverişlerde kargo şirketini seçebilme imkânı olması, ürün tesliminin üç iş günü içinde olmasının a) online alışveriş niyeti, b) online tüketici tatmini ve c) algilanan hizmet kalitesi üzerindeki pozitif etkisini artırmaktadır. 


\section{Yöntem}

Hipotezleri test etmek için senaryo bazlı deney yönteminden yararlanılmıştır. Online alışveriş yapanların kargo ile ilgili alışveriş deneyimlerini simüle etmek ve ürünlerin kargolanması ile ilgili farklı uygulamaların tüketiciler üzerindeki etkilerini incelemek için senaryolar kullanılmıştır. Araştırmaya toplam 202 lisans öğrencisi katılmıştır. Katılımcılar ile ilgili demografik bilgiler Tablo 1'de gösterilmiştir.

Tablo 1. Katılımcıların demografik özellikleri

\begin{tabular}{lllllllll}
\hline Cinsiyet & S & $\%$ & Gelir & S & $\%$ & Yaş & S & $\%$ \\
\hline Erkek & 82 & 40,59 & $0-2324$ TL & 43 & 21,3 & 18 & 21 & 10,4 \\
Kadın & 120 & 59,41 & 2325-4648 TL & 65 & 32,2 & 19 & 23 & 11,4 \\
Toplam & 202 & \multirow{2}{*}{100} & $4649-6972 \mathrm{TL}$ & 35 & 17,3 & 20 & 57 & 28,2 \\
& & & 6973-9296 TL & 26 & 12,9 & 21 & 72 & 35,6 \\
& & & 9297-11620 TL & 21 & 10,4 & 22 & 17 & 8,4 \\
& & & 11621 TL+ & 12 & 5,94 & $23+$ & 12 & 5,9 \\
& & Toplam & 202 & 100 & Toplam & 202 & 100 \\
\hline
\end{tabular}

Veriler dersin başlangıcından önce öğrencilere dağıtılan bir anket aracilığıyla toplanmıştır. Katılımcılara online alışveriş ile ilgili rasgele dağıtılmış senaryoları okumaları ve bu durumda olduklarını hayal etmeleri istenmiştir. Senaryolarda online mağazaların kargo ücretini tahsil etme zamanı, sattığı ürünleri tüketicilere ulaştırma süreleri ve müşterilerine istediği kargo şirketini seçme imkanı tanıma durumları manipüle edilmiştir. Senaryoyu okuduktan sonra katılımcılar, pazarlama araştırmalarında oldukça sık kullanılan değişkenler olan online alışveriş niyeti, online tüketici tatmini ve algılanan hizmet kalitesi ile ilgili soruları içeren bir anket doldurmuşlardır. Çalışmada kullanılan bağımlı değişkenleri ölçmek için kullanılan ölçekler mevcut literatürden alınmıştır ve çalışmaya uyarlanmıştır. Her bir değişkeni ölçmek için yedili likert tipi ölçek ("Kesinlikle katılmıyorum"'dan - "Kesinlikle katılıyorum"'’a doğru değişen) kullanılmıştır.

Bu araştırmada daha önceden literatürde kullanılmış olan değişkenlerden yararlanıldığ için doğrulayıcı faktör analizi yapılmıştır. Analiz sonuçları ortaya çıkan değerlerin tatmin edici olduğunu göstermektedir (Hu ve Bentler 1999): $\mathrm{CFI}=$ 0.94, GFI $=0.84$, AGFI $=0.81, \mathrm{RFI}=0.89, \mathrm{NFI}=0.91, \mathrm{TLI}=0.91, \mathrm{IFI}=0.93$, RMSEA $=0,078$. Güvenilirlik için bileşik güvenirlik ve cronbach alfa değerleri 
incelenmiş ve birbirine çok yakın sonuçlar verdiği ve her ölçeğin gerekli olan 0,8 değerini aştığ gözlemlenmiştir (Churchill, 1979; Hair vd., 2010). Faktör yükleri incelendiğinde sonuçların 0,73 ile 0,84 arasında değiştiği görülmüştür. Sonuçlar Tablo 2'de gösterilmiştir.

Tablo 2. Ölçek yükleri, ortalama ve standart sapma değerleri

\begin{tabular}{|c|c|c|c|}
\hline Ölçek öğeleri & $\begin{array}{l}\text { Ortalama } \\
\text { (SS) }\end{array}$ & Yükler & Kaynak \\
\hline Online Alışveriş Niyeti $(\alpha=0.81)$ & & & $\begin{array}{l}\text { Jones ve } \\
\text { Kim }(2010)\end{array}$ \\
\hline Bu online mağazadan alışveriş yapmak isterim. & $4,75(1,92)$ & 0,81 & \\
\hline Bu online mağazadan ürün arama ihtimalim yüksektir. & $4,77(1,91)$ & 0,82 & \\
\hline Bu online mağazayı arkadaşlarıma tavsiye etmek isterim. & $4,72(2)$ & 0,75 & \\
\hline Algılanan Hizmet Kalitesi $(\alpha=0.84)$ & & & $\begin{array}{l}\text { Wang vd. } \\
(2010)\end{array}$ \\
\hline $\begin{array}{l}\text { Bu online mağaza geniş bir kargo hizmeti seçeneği sunmak- } \\
\text { tadır }\end{array}$ & $4,86(1,98)$ & 0,82 & \\
\hline $\begin{array}{l}\text { Bu online mağaza istediğim özellikte kargo hizmeti vermekte- } \\
\text { dir. }\end{array}$ & $4,82(1,95)$ & 0,84 & \\
\hline $\begin{array}{l}\text { Bu online mağaza ihtiyacım olan kargo hizmetlerinin çoğunu } \\
\text { sağlamaktadır. }\end{array}$ & $4,83(1,92)$ & 0,80 & \\
\hline $\begin{array}{l}\text { Bu online mağazada tüm kargo hizmeti ihtiyaçlarım yer } \\
\text { almaktadır. }\end{array}$ & $4,68(1,99)$ & 0,77 & \\
\hline Online Tüketici Tatmini $(\alpha=0.88)$ & & & $\begin{array}{l}\text { Cao } \\
\text { vd. (2018) }\end{array}$ \\
\hline Bu online mağaza tarafından sağlanan hizmetler çok iyidir. & $4,84(1,83)$ & 0,77 & \\
\hline $\begin{array}{l}\text { Bu online mağaza iyi bir müşteri hizmet kalitesi sağla- } \\
\text { maktadır. }\end{array}$ & $4,93(1,84)$ & 0,76 & \\
\hline $\mathrm{Bu}$ online mağazadan alışveriş deneyimim tatmin edicidir. & $4,9(1,98)$ & 0,74 & \\
\hline Bu online mağazadaki alışverişimden memnun kalırım. & $4,74(1,94)$ & 0,73 & \\
\hline
\end{tabular}

Katılımcların araştırmada kullanılan manipülasyonları doğru bir şekilde anlayıp anlamadığın kontrol edebilmek için çeşitli sorular sorulmuştur. Bu sorulardan bazıları şu şekildedir: Bu online mağaza sattığı ürünlerin kargo ücretini ürün ücreti ödenirken tahsil etmektedir, bu online mağaza ürünlerini 3 iş günü içerisinde ulaştıracağını taahhüt etmektedir, bu online mağaza müşterilerine kargo şirketini seçebilme imkanı tanımaktadır. Manipülasyon testi sonuçlarına göre katılımcların manipülasyonları istenen şekilde algıladıkları görülmektedir (Osatın alma $=5,55>$ Oeline geçince $=1,59, \mathrm{p}<0.001$; $\mathrm{O} 3$ iş günü $=5,12>\mathrm{O} 4-6$ iş günü $=2,13, \mathrm{p}<0.001$; Okargo seçme $=5,67>$ Okargo seçememe $=2,03, \mathrm{p}<0.001$ ). Araştırmada kullanılan senaryoların katılımcılar tarafından gerçekçi olarak algılanıp algılanmadığı da "Senaryoda tanımlanan 
durum gerçekçidir, kendimi senaryoda tanımlanan durum içinde görebiliyorum." soruları ile kontrol edildi. Sonuçlara göre katılımcıların cevap ortalamaları yüksek olduğu için $(\mathrm{O}=5,07 ; \mathrm{SS}=1,23)$, senaryoların katılımcılar tarafından gerçekçi bulunduğu sonucuna ulaşılmıştır (Dabholkar, 1994).

\section{Bulgular}

Hipotezlerin test edilmesinde çok değişkenli varyans analizinden (MANOVA) yararlanılmıştır. Tahsil zamanı (Wilks' lambda $=0.914 ; \mathrm{F}=5.99$; $\mathrm{p}=0.001$ ), ulaşma süresi (Wilks' lambda $=0.814 ; \mathrm{F}=14.66 ; \mathrm{p}<0.001$ ) ve seçme imkanınin (Wilks' lambda $=0.864 ; \mathrm{F}=10.05 ; \mathrm{p}<0.001$ ) anlamlı ana etkileri gözlenmiştir. Bu ana etkilerin detaylarını ve ikili etkileri incelemek ve hipotezleri değerlendirmek için tek değişkenli analiz kullanılmış, sonuçlar Tablo 3'de gösterilmiştir.

Tablo 3: Ana etkiler ve etkileşim etkileri için tek değişkenli varyans ve F istatistiği

\begin{tabular}{llll}
\hline & Alş̧veriş Niyeti & Tüketici Tatmini & Hizmet Kalitesi \\
\hline Tahsil Zamanı (T) & $14.46(\mathrm{p}<0.001)$ & $9.78(\mathrm{p}=0.002)$ & $13.54(\mathrm{p}<0.001)$ \\
\hline Ulaşma Süresi (U) & $36.11(\mathrm{p}<0.001)$ & $26.68(\mathrm{p}<0.001)$ & $30.84(\mathrm{p}<0.001)$ \\
\hline Seçme İmkanı (S) & $26.23(\mathrm{p}<0.001)$ & $8.82(\mathrm{p}=0.003)$ & $20.55(\mathrm{p}<0.001)$ \\
\hline T x U & $1.06(\mathrm{p}=0.304)$ & $4.97(\mathrm{p}=0.027)$ & $4.18(\mathrm{p}=0.042)$ \\
\hline T x S & $10.22(\mathrm{p}=0.002)$ & $4.49(\mathrm{p}=0.035)$ & $7.55(\mathrm{p}=0.007)$ \\
\hline S x U & $4.26(\mathrm{p}=0.040)$ & $8.05(\mathrm{p}=0.005)$ & $10.77(\mathrm{p}=0.001)$ \\
\hline
\end{tabular}

Tablo 3 incelendiğinde sonuçların H1a-c, H2a-c ve H3a-c'yi desteklediği görülmektedir. Online alışverişlerde kargo ücretinin satın alma sırasında ödenmesinin, ürün tüketiciye ulaştığında ödenmesine kıyasla, ürün tesliminin üç iş günü içinde olmasının, dört-altı iş günü içinde olmasına kıyasla ve kargo şirketini seçebilme imkânı olmasının, olmamasına kıyasla online alışveriş niyeti, online tüketici tatmini ve algılanan hizmet kalitesi üzerinde daha fazla pozitif etkileri olduğu gözlemlenmiştir. 

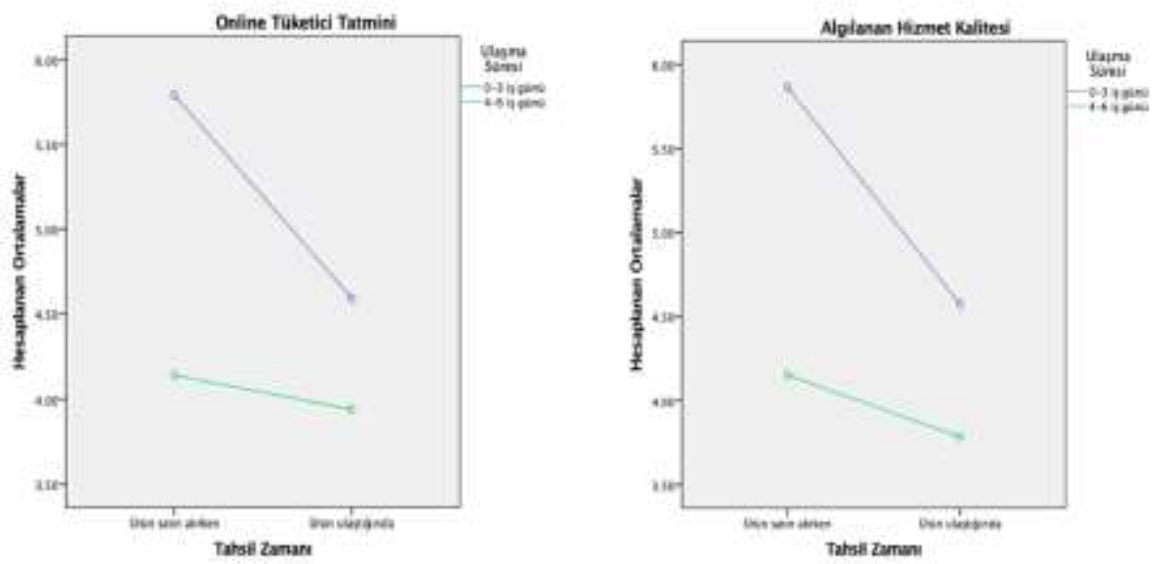

Grafik 1. Kargo ücretinin tahsil zaman ve kargonun ulaşma süresinin online tüketici tatmini ve algılanan hizmet kalitesi üzerinde etkisi

Analiz sonuçları ikili etkileşimlerde de anlamlı bulguları ortaya çıkartmıştır. Kargo ücretinin tahsil zaman ile kargonun ulaşma süresinin ikili etkileşimi sadece online tüketici tatmini $(\mathrm{F}=4.97 ; \mathrm{p}=0.027)$ ve algılanan hizmet kalitesi $(\mathrm{F}=4.18 ; \mathrm{p}=0.042)$ üzerinde anlamlı etkiye sahiptir. Dolayısıyla $\mathrm{H} 4 \mathrm{a}$ reddedilmiş, $\mathrm{H} 4 \mathrm{~b}$ ve $\mathrm{H} 4 \mathrm{c}$ desteklenmiştir. Grafik 1'de gösterildiği gibi online alışverişlerde kargo ücretinin satın alma sırasında ödenebiliyor olması, ürün tesliminin üç iş günü içinde olmasının online tüketici tatmini ve algilanan hizmet kalitesi üzerindeki pozitif etkisini artırmaktadır.
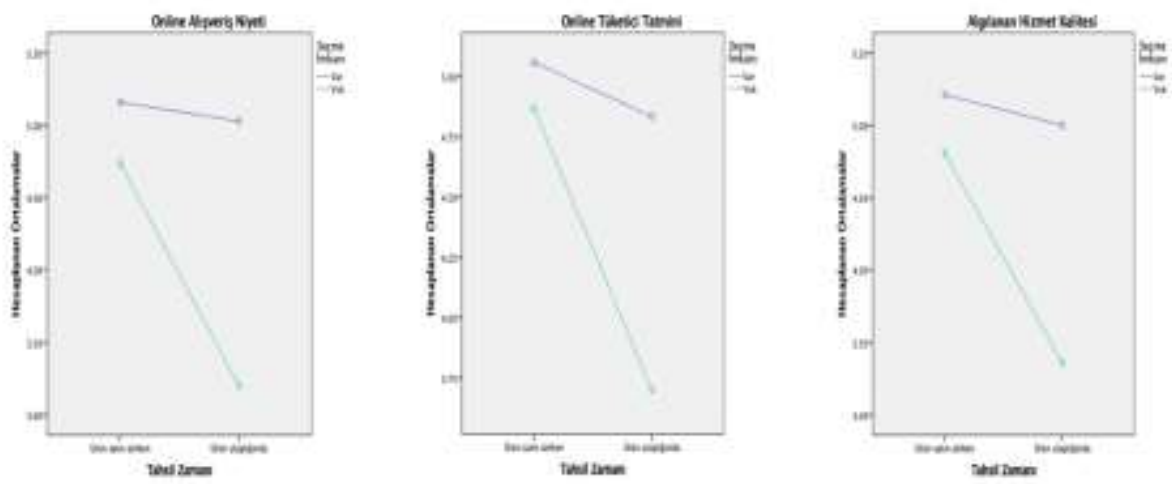

Grafik 2. Kargo ïcretinin tahsil zamanı ve kargo şirketini seçme imkanının online alışveriş niyeti, online tüketici tatmini ve algılanan hizmet kalitesi üzerinde etkisi 
Kargo ücretinin tahsil zamanı ile kargo şirketini seçme imkanının ikili etkileşiminin online alışveriş niyeti $(\mathrm{F}=10.22 ; \mathrm{p}=0.002)$, online tüketici tatmini $(\mathrm{F}=4.49 ; \mathrm{p}=0.035)$ ve algılanan hizmet kalitesi $(\mathrm{F}=7.55 ; \mathrm{p}=0.007)$ üzerinde anlamlı etkileri gözlemlenmiştir. Bu sonuca göre $\mathrm{H} 5 \mathrm{a}, \mathrm{H} 5 \mathrm{~b}$ ve $\mathrm{H} 5 \mathrm{c}$ desteklenmiştir. Grafik 2' de görüldüğü gibi online alışverişlerde kargo ücretinin satın alma sırasında ödenebiliyor olması, kargo şirketini seçebilme imkânı olmasının online alışveriş niyeti, online tüketici tatmini ve algılanan hizmet kalitesi üzerindeki pozitif etkisini artırmaktadır.
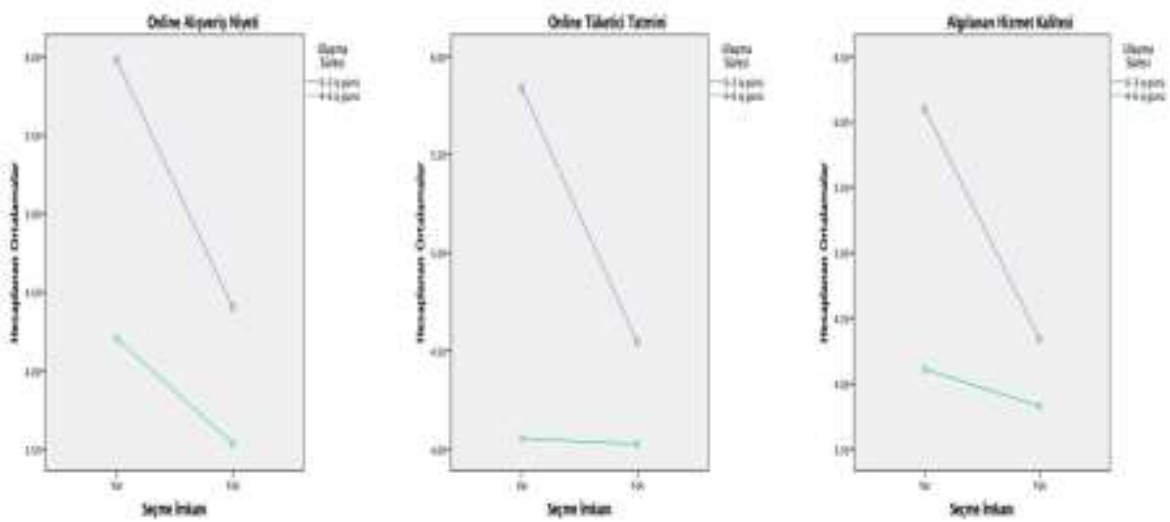

Grafik 3. Kargo şirketini seçme imkanı ve kargonun ulaşma süresinin online alışveriş niyeti, online tüketici tatmini ve algılanan hizmet kalitesi üzerinde etkisi

Son gözlemlenen istatistiki olarak anlamlı ilişki kargo şirketini seçme imkanı ile kargonun ulaşma süresinin ikili etkileşiminin online alışveriş niyeti $(\mathrm{F}=4.26 ; \mathrm{p}=0.040)$, online tüketici tatmini $(\mathrm{F}=8.05 ; \mathrm{p}=0.005)$ ve algılanan hizmet kalitesi ( $\mathrm{F}=10.77 ; \mathrm{p}=0.001)$ üzerindeki etkileridir. Yani H6a, H6b ve H6c desteklenmiştir. Grafik 3'ün gösterdiği gibi online alışverişlerde kargo şirketini seçebilme imkânı olması, ürün tesliminin üç iş günü içinde olmasının online alışveriş niyeti, online tüketici tatmini ve algılanan hizmet kalitesi üzerindeki pozitif etkisini artırmaktadır. 


\section{Tartışma ve Sonuç}

Tüketiciler için internet siteleri üzerinden satın aldıkları ürünlerin kargo ücretlerinin ödenmesinde satın alma zamanında ödeme ve ürün tüketicinin eline ulaştığı zaman ödeme arasında farklı tutumlar olduğu tespit edilmiştir. Tüketici tatmininde görülen bu farklılıklar ürünlerin tüketicilere 0-3 gün ile 3-6 gün arasında teslim edilmesine göre farklılaşmaktadır. Ürünün teslim edilme süresi farketmeksizin kargo ücretinin ürünlerin satın alma zamanında ödenmesi halinde daha yüksek olduğu, ancak ürün tüketiciye ulaştığında kargo ücretinin ödenmesinin tüketici tatmini açısından yine yüksek seviyelerde olmakla birlikte, önceden ödenmeye göre azaldığı görülmektedir. Süreler kıyaslandığında ise ürünlerine tüketicilerin eline ulaşma süresinin kısa oluşu, kargo ücretinin önce veya sonra ödenmesi durumunda bile 3-6 gün arasında geçmesinden daha yüksek bir tüketici tatminine yol açmaktadır.

Algılanan hizmet kalitesi açısından incelendiğinde de online tüketici tatminin ile benzer sonuçlar elde edildiği görülmektedir. Ürünler tüketicilere 0-3 gün arasında ulaştığında tüketicilerin algıladıkları hizmet kalitesi 3-6 gün arasında ulaşmasına kıyasla daha yüksek olmaktadır. Kargo ücretlerinin ürünün satın alındığı zaman ödenmesi durumunda ise her iki durumda da hizmet kalitesi algısı daha yüksek olurken, kargo ücreti ürünün tesliminde ödendiğinden algılanan hizmet kalitesinde bir miktar azalma olduğu belirlenmiştir. Bu azalma miktarı 0-3gün arası teslim süresinde daha yüksek olmakla birlikte, azalan bu hizmet kalitesi algısı yine de 3-6 gün arası teslim seçeneğine göre daha yüksek seviyededir.

Özet olarak online alışverişlerde tüketicilerin tatmin seviyeleri ve algıladıkları hizmet kalitesinin daha hızlı ürün tesliminde yüksek olurken, aynı zamanda kargo ücretinin ürünün satın alındığı zamanda ödenmesinin de hem tüketici tatmini hem de hizmet kalitesi algısını yükselttiği görülmektedir. Bu durumun nedeni olarak tüketicileri hem ürün satın alırken ürünlerin ücretlerinin, hem de teslim anında kargo ücreti ödemek suretiyle ayn ürün için sanki iki defa ödeme yapıyormuş gibi hissetmeleri gösterilebilir. Oysa ki satın alma esnasında ödeme yapıldığında tek seferde yapılan bir ödeme gibi algilandığı ortaya çıkmıştır. Gerçekte ise kargo ücreti ister ürün satın alımı esnasinda ster ürün tesliminde ödensin, tüketicilerin ödeyecekleri rakam değişmemektedir. 
Günümüzde kargo hizmeti veren birçok işletme mevcuttur. Birbirlerine rakip konumunda olan bu şirketler varlıklarını sürdürebilmek için rakiplerinden daha iyi hizmet sunarak müşteri memnuniyetlerini artırmaya ve kazançlarını da yükseltmeye çalışmaktadırlar. Birçok işletme için olduğu gibi kargo firmalarında da tüketiciler daha yüksek memnuniyete sahip oldukları işletmelere yönelmektedirler. Bu durumun farkında olan satıcı işletmeler de kendi tüketicileri için satın aldıkları ürünlerin tesliminde istedikleri kargo firmasını seçebilme opsiyonu sunabilmektedirler. Kargo firmasını seçme imkanı bulunduğunda tüketicilerin online sitelerden alışveriş yapma niyetlerinin seçim imkanı olmadığı durumlara göre daha yüksek olduğu tespit edilmiştir. H5a hipotezi de bu sonuçlarla desteklenmektedir. Kargo ücretlerinin satın alma esnasında ödenmesi alışveriş niyetini artırırken, ürün tesliminde ödenmesi durumunda bu niyette azalma görülmektedir. Kargo firması seçme imkanı bulunduğunda alışveriş niyetindeki azalma oldukça düşük bir seviyede gerçekleşirken, kargo firması seçilemediğinde ve kargo ücreti ürün tesliminde ödendiğinde alışveriş niyetindeki azalma belirgin biçimde azalmaktadır. Bir önceki hipotezde kargo ücretinin ürün tesliminde ödenmesinin tüketicinin algısında nasıl olumsuz bir algıya yol açtığından bahsedilmişti. Kargo firmasının seçilebildiği durumlarda tüketicilerin alışveriş niyetinde fazla değişim olmaması, kargo firmaları ile ilgili olarak bir memnuniyetsizlik yaşansa dahi, tüketicilerin kendi seçimlerinin bir sonucu olarak değerlendirmesi olarak düşünülebilir. Oysa ki kargo firması seçme imkanı bulunmadığında tüketiciler olumsuz tecrübe yaşanma ihtimali karşısında kendilerinin bir etkisi bulunamayacağını düşünerek sadece bu sebepten bile bir siteden alışveriş yapmaktan vazgeçebilmektedirler.

Online alışveriş niyetinde olduğu gibi, tüketici tatmini ile ilgili yapılan analizlerde de sonuçlar önceki analizlerle benzerlikler göstermektedir. Online tüketici tatmini, tüketicilerin kargo firmasını seçim imkanına sahip olduğu durumlarda daha yüksek olmaktadır. Kargo firmasının seçilebilmesinin yanı sıra, kargo ücretinin ürün satın alındığında ödenmesi durumunda tüketici tatmini kargo ücretinin ürün tesliminde ödenmesine göre daha yüksek olduğu görülmektedir. Tipkı alışveriş niyetinde olduğu gibi tüketici tatmininde de hem kargo ücretinin ödenmesinin gecikmesi hem de kargo firması seçiminde tüketicinin alternatiflere sahip olmaması tüketici tatmininde önemli ölçüde azalmaya neden olmaktadır. 
Kargo firması seçim imkanı bulunması ve kargo ücretinin tahsilatının ürün satın alınırken gerçekleşmesi tüketicilerin algıladıkları hizmet kalitesinin daha yüksek olmasına sebep olmaktadır. Aslında önceki iki hipoteze dair sonuçlarla birlikte değerlendirildiğinde, yani online alışveriş niyeti ve tüketici tatminini artıran durumlarda tüketiciler için satın aldıkları hizmetin daha kaliteli olarak algılanacağı da beklenen bir sonuçtur. Tüketiciler birçok konuda olduğu gibi, ürünleri kedilerine ulaştıracak kargo firmalarının seçiminde de kontrolün kendilerinde olmasını istemektedirler. Kontrollerinin azaldığı durumlarda tatminleri ve kalite algıları da bu durumdan olumsuz biçimde etkilenmektedir. Bir diğer istenmeyen durum da kargo ücretinin ürün teslimi sırasında tahsil edilmesidir. Aslında bu durum tüketiciler tarafında daha fazla tercih edilebilecek bir alternatif gibi düşünülebilir. Birçok tüketici online olarak satın aldıkları ürünler, kendilerine ulaşana kadar birtakım riskler ve endişeler taşımaktadırlar. Bu nedenle kargo ücretinin, ürünlerin tesliminde ödenecek olması, algilanan bu risklerin en azından bir kısmının azaltılmasında yararlı olabilecektir. Ancak analizlerden elde edilen sonuçlar bu durumun tam tersine işaret etmektedir. Buradan çıkarabilecek sonuç ise tüketicilerin ancak kesin olarak güven duydukları alışveriş sitelerinden online olarak ürün veya hizmet satın aldıklarıdır.

Online alışveriş niyetinin kargo firması seçim imkanı olması durumunda daha yüksek olduğu görülmektedir. Ürünlerin teslim sürelerinin 0-3 gün arasında olması ise 3-6 gün arasında olmasına göre online alışveriş niyetinin artıran bir diğer faktördür. Tüketicilerin online alışveriş niyetinde, ürünlerin teslim süresinin, kargo firması seçim imkanından daha önemli bir rol oynadığı görülmektedir. Tüketicilerin kargo firması seçemediği ancak teslim süresinin 3-6 gün arası olduğu durumlarda bile online alışveriş niyetlerinin, kargo firması seçebildiği, ancak ürünlerin 3-6 gün arasında teslim edildiği durumlara kıyasla daha yüksek tespit edilmiştir. Bu durum H6a hipotezini desteklemektedir. Sonuç olarak satıcı işletmelerin, tüketicilerin alışveriş niyetlerini artırabilmek için ilk olarak ürün teslimat sürelerinin kısaltmaları, ikincil olarak ise kendilerine kargo firması seçimi ile ilgili alternatif seçenekler sunmaları faydalı olacaktır.

Online tüketici tatmini de ürünlerin teslim süreleri ve tüketicilerin kargo firması seçim imkanına sahip olup olmamasından etkilenen bir değişkendir. Online alışveriş yapan tüketicilerin tatmin seviyesi ürün teslimatının 0-3 gün içerisinde gerçekleştiği durumlarda 3-6 gün arasında yapılan teslimatlara 
göre daha yüksek olmaktadır. H6b hipotezinin de bu sonuçlarla desteklendiği görülmektedir. Ürün teslimatının daha uzun sürede gerçekleştiği durumda kargo firması seçim imkanının bulunup bulunmaması, tüketicilerin tatmin seviyesinde neredeyse hiçbir farklılığa yol açmazken, kısa sürede gerçekleştirilen ürün teslimatlarında, kargo firmasının seçilemediği durumlarda tüketici memnuniyeti gözle görülür biçimde azalmaktadır.

Tüketicilerin algıladıkları hizmet kalitesi de alışveriş niyeti ve tüketici tatmini gibi ürün teslimatının hızlı yapılması durumunda daha yüksek olmaktadır. Bu durumda tüketiciler için iyi bir hizmetin daha hızlı gerçekleştirilen hizmet anlamına geldiği söylenebilir. Şimdiye kadar test edilen tüm hipotezlerde ürün teslimatının 0-3 gün içinde gerçekleştiği durumlarda tüketicilerin algıları ve tutumları daha olumlu olmaktadır. Ürünlerin teslimatını gerçekleştiren kargo firmalarının seçimine dair bir opsiyon ise olumlu anlamda katkı sağlasa da teslimat süresine göre daha küçük etkilere sahiptir. Bu durumun en belirgin göstergesi ise ürün teslimatının 3-6 iş günü içinde gerçekleştiği durumlarda, kargo firmasının seçilebilmesinin alışveriş niyeti, tüketici tatmini ve hizmet kalitesi algısında önemli değişikliklere yol açmamasıdır. Kargo firmasının seçilebiliyor olması elbette ki önemsiz bir faktör değildir, ancak etkisi ürün teslimatının daha huzlı gerçekleştiği durumlarda daha yüksek olmaktadır.

Son olarak her çalışmada olduğu gibi bu çalışmanın da bazı kısıtları vardır. Çalışmada kolayda örnekleme yöntemiyle lisans öğrencilerinden veri toplanmış ve bu da sonuçların genelleştirilebilmesi açısından bir kısıt teşkil etmiştir. İleriki çalışmalar daha genellenebilir bir örneklem seçimi ile yapılabilir. Bu araştırmada kargo hizmetlerinin tüketici algıları üzerindeki etkisini ölçmek için senaryo bazlı deney yönteminden yararlanılmış ve kargo ücretinin tahsil zamanı, kargonun ulaşma süresi ve kargo şirketini seçme imkanı manipüle edilmiştir. Ancak kargo şirketlerinin sunduğu hizmetler sadece bu çalışmada kullanılanlarla sınırlı değildir. Gelecek çalışmalar özellikle gelişen teknolojiyle beraber ortaya çıkan otomatik kargo istasyonları (Chen vd., 2020) gibi yeni hizmetlerin de tüketicilerin tercihlerine etkisini araştırabilir. 


\title{
EXTENDED ABSTRACT
}

\section{The Effect of Courier Services on Consumer Perceptions in Online Shopping}

\author{
Mertcan Taşçığlu \\ İstanbul Medeniyet University
}

Today, consumers do not have the opportunity to allocate enough time for shopping in their daily lives. Both the intensity of business life and the difficulty of reaching different stores for shopping have led consumers to be directed to online shopping sites. In recent years, significant developments have occurred in the field of electronic commerce both in the world and in our country, and large capitalists have concentrated investments in this area. Being one of the richest people in the world today, Jeff Bezos is the founder and owner of Amazon.com, one of the biggest companies in the world in online trade. The fact that Amazon.com became a company that earned an annual income of 279 billion dollars (Forbes, 2019) for a business such as 25 years (1994 - 2019) since its foundation (Forbes, 2019) has led other businesses to invest in electronic commerce. The share of online shopping will continue to grow in the coming years.

This new situation has also caused some changes in consumers' expectations and satisfaction criteria. With online shopping, it has become important for products to reach the consumers in the fastest and easiest way. As there is an increase in the number of courier companies operating for this purpose, some online sales sites have established their own cargo distribution systems. Although consumers buy products from the internet, delivery of products to consumers through cargo companies is evaluated in the field of service.. The most important difference between services and products is that they are intangible. It is more difficult to evaluate services that are intangible and to compare service businesses to products. It is very difficult to provide a standard in service delivery. Courier firms are also affected by this situation, and they can cause many dissatisfaction with consumers. Today, consumers both demand their elimination of negative situations and punish businesses in a sense by either conveying their complaints to the relevant business or sharing with other consumers. There are websites operating only to share consumer 
complaints. When these sites are examined, it is seen that there are quite a lot of complaints about courier companies.

It may be difficult to provide the services in the same areas in all regions. For this reason, while complaints from some courier companies are concentrated in some regions, the services of the same company in a different region can satisfy the consumers. There may be seasonal problems in the services. Activities such as "Crazy Friday" and "Legendary Friday", which have become widespread in our country in recent years, cause the consumers to shop much more than normal times by reaching the discounts they expect throughout the year. However, as a result of this, the burden of courier companies increases at a very high rate and consumers have to wait for a long time to deliver the products. For example, this waiting period has found weeks during the campaign period in 2019. Long waiting times can have a negative impact on consumers' satisfaction with their shopping.

Another situation that consumers encounter when shopping online is the stage at which the shipping fee will be paid. The shipping fee can be paid while purchasing the product or it can be paid during the delivery of the product. Both situations have advantages for consumers. For example, paying the shipping fee in the delivery of the product is a preferable option in the event that there is a problem in the incoming product, while the payment at the time of purchase causes the consumers to consider the shipping fee as a part of the product price and evaluate it as a single price.

In this study, using the scenario-based experiment method, the time of collecting the shipping fee, the shipping time and the possibility of choosing the courier company were manipulated and the effects on the online shopping intention, online consumer satisfaction and perceived service quality were examined. The results show that during the online shopping the fact that the shipping fee can be paid at the time of purchase increases the positive impact of the product delivery within three days on online consumer satisfaction, and perceived service quality. Another result is the fact that the shipping fee can be paid at the time of purchase increases the positive impact of having the opportunity to choose the courier company on online shopping intention, online consumer satisfaction, and perceived service quality. Finally having the opportunity to choose the courier company increases the positive impact of of the product delivery within three days on online shopping intention, online consumer satisfaction, and perceived service quality. 


\section{Kaynakça / References}

Abramovic, G. (2019). 15 Mind-blowing stats about online shopping in 2019. 15 Kasım 2019 tarihinde https://cmo.adobe.com/articles/2014/5/Mind Blowing Stats Online Shopping.html adresinden erişildi.

Ahn, T., Ryu, S., ve Han, I. (2007). The impact of Web quality and playfulness on user acceptance of online retailing. Information \& Management, 44(3), 263275.

Alreck, P. L., DiBartolo, G. R., Diriker, M., Dover, H. F., Passyn, K. A., ve Settle, R. B. (2009). Time pressure, time saving and online shopping: exploring a contradiction. Journal of Applied Business Research (JABR), 25(5), 85-92.

Bhattacherjee, A. (2001). An empirical analysis of the antecedents of electronic commerce service continuance. Decision Support Systems, 32(2), 201-214.

Bitner, M. J. (1990). Evaluating service encounters: the effects of physical surroundings and employee responses. Journal of Marketing, 54(2), 69-82.

Bolton, R. N., \& Drew, J. H. (1991). A longitudinal analysis of the impact of service changes on customer attitudes. Journal of Marketing, 55(1), 1-9.

Boulding, W., Kalra, A., Staelin, R., ve Zeithaml, V. A. (1993). A dynamic process model of service quality: from expectations to behavioral intentions. Journal of Marketing Research, 30(1), 7-27.

Cao, Y., Ajjan, H., ve Hong, P. (2018). Post-purchase shipping and customer service experiences in online shopping and their impact on customer satisfaction. Asia Pacific Journal of Marketing and Logistics, 30(2), 400-416.

Chen, C. F., White, C., ve Hsieh, Y. E. (2020). The role of consumer participation readiness in automated parcel station usage intentions. Journal of Retailing and Consumer Services, 54, 1-6.

Churchill, G.A. (1979). A paradigm for developing better measures of marketing constructs. Journal of Marketing Research, 16(1), 64-73.

Cronin Jr, J. J., ve Taylor, S. A. (1992). Measuring service quality: a reexamination and extension. Journal of Marketing, 56(3), 55-68.

Dabholkar, P.A. (1994). Incorporating choice into an attitudinal framework: Analyzing models of mental comparison processes. Journal of Consumer Research, 21(1), 100-118.

Forbes (2019). Amazon to beat consensus estimates for FY 2019? 1 Kasım 2019 tarihinde https://www.forbes.com/sites/greatspeculations/2020/01/28/amazon-to-beat-consensus-estimates-for-fy-2019/ adresinden erişildi.

Hair, J. F., Black, W. C., ve Babin, B. J. (2010). Multivariate data analysis: A global perspective. New Jersey, Pearson Prentice Hall 
Ho, C. F., ve Wu, W. H. (1999). Antecedents of customer satisfaction on the Internet: an empirical study of online shopping. In Proceedings of the 32nd Annual Hawaii International Conference on Systems Sciences. 1999. HICSS-32. Abstracts and CD-ROM of Full Papers (p. 9). IEEE.

Hu, L.T. ve Bentler, P.M. (1999). Cutoff criteria for fit indexes in covariance structure analysis: Conventional criteria versus new alternatives. Structural Equation Modeling, 6(1), 1-55

Jahng, J., Jain, H., ve Ramamurthy, K. (2001). The impact of electronic commerce environment on user behavior: The case of a complex product. E-Service, 1(1), 41-53.

Jarvenpaa, S. L., Tractinsky, N., ve Vitale, M. (2000). Consumer trust in an Internet store. Information Technology and Management, 1(1-2), 45-71.

Jones, C., ve Kim, S. (2010). Influences of retail brand trust, off-line patronage, clothing involvement and website quality on online apparel shopping intention. International Journal of Consumer Studies, 34(6), 627-637.

Khalifa, M., ve Liu, V. (2007). Online consumer retention: contingent effects of online shopping habit and online shopping experience. European Journal of Information Systems, 16(6), 780-792.

Kim, E., Eom, S., ve Uoo, S. (2001). Effective user interface design for online stores in the Asia Pacific region: A survey study. AMCIS 2001 Proceedings, 168.

Li, N., ve Zhang, P. (2002). Consumer online shopping attitudes and behavior: An assessment of research. AMCIS 2002 Proceedings, 74.

Nanji, A. (2013). Online shopping trends 2013: Most popular categories, top purchase drivers. 27 Ekim 2019 tarihinde http://www.marketingprofs.com/charts/2013/12195/online-shopping-trends-most-popularcategories-top-purchase-drivers/ adresinden erişildi.

Nepomuceno, M. V., Laroche, M., ve Richard, M. O. (2014). How to reduce perceived risk when buying online: The interactions between intangibility, product knowledge, brand familiarity, privacy and security concerns. Journal of Retailing and Consumer Services, 21(4), 619-629.

Oliver, R. L., ve DeSarbo, W. S. (1989). Processing of the satisfaction response in consumption: a suggested framework and research propositions. Journal of Consumer Satisfaction, Dissatisfaction and Complaining Behavior, 2(1), 1-16.

Oliver, R. L. (1993). A conceptual model of service quality and service satisfaction: Comparative goals, different concepts. Advances in Service Marketing and Management, 2, 65-85. 
Parasuraman, A., Zeithaml, V. A., ve Berry, L. L. (1994). Alternative scales for measuring service quality: a comparative assessment based on psychometric and diagnostic criteria. Journal of Retailing, 70(3), 201-230.

Santouridis, I., Trivellas, P., ve Reklitis, P. (2009). Internet service quality and customer satisfaction: examining internet banking in Greece. Total Quality Management, 20(2), 223-239.

Spreng, R. A., ve Mackoy, R. D. (1996). An empirical examination of a model of perceived service quality and satisfaction. Journal of Retailing, 72(2), 201-214.

Wang, Y. J., Hernandez, M. D., ve Minor, M. S. (2010). Web aesthetics effects on perceived online service quality and satisfaction in an e-tail environment: The moderating role of purchase task. Journal of Business Research, 63(910), 935-942.

Verhagen, T., Vonkeman, C., Feldberg, F., ve Verhagen, P. (2014). Present it like it is here: Creating local presence to improve online product experiences. Computers in human behavior, 39, 270-280.

Zeithaml, V. A., Parasuraman, A., ve Malhotra, A. (2002). Service quality delivery through web sites: a critical review of extant knowledge. Journal of the Academy of Marketing Science, 30(4), 362-375.

Zeithaml, V. A., Berry, L. L., ve Parasuraman, A. (1993). The nature and determinants of customer expectations of service. Journal of the Academy of Marketing Science, 21(1), 1-12.

\section{Kaynakça Bilgisi / Citation Information}

Taşçıŏlu, M. (2020). Online alışverişlerde kargo hizmetlerinin tüketici algılarına etkisi. OPUS-Uluslararası Toplum Araştırmaları Dergisi, 15(23), 2011-2030. DOI: 10.26466/opus.681809 